\title{
Assessment of potential biomass energy production in China towards 2030 and 2050
}

\section{Zhao, Guangling}

Published in:

International Journal of Sustainable Energy

Link to article, DOI:

$10.1080 / 14786451.2016 .1231677$

Publication date:

2018

Document Version

Peer reviewed version

Link back to DTU Orbit

Citation (APA):

Zhao, G. (2018). Assessment of potential biomass energy production in China towards 2030 and 2050.

International Journal of Sustainable Energy, 37(1), 47-66. https://doi.org/10.1080/14786451.2016.1231677

\section{General rights}

Copyright and moral rights for the publications made accessible in the public portal are retained by the authors and/or other copyright owners and it is a condition of accessing publications that users recognise and abide by the legal requirements associated with these rights.

- Users may download and print one copy of any publication from the public portal for the purpose of private study or research.

- You may not further distribute the material or use it for any profit-making activity or commercial gain

- You may freely distribute the URL identifying the publication in the public portal

If you believe that this document breaches copyright please contact us providing details, and we will remove access to the work immediately and investigate your claim. 


\title{
Assessment of Potential Biomass Energy Production in China towards 2030 and 2050
}

\author{
Author: Guangling Zhao \\ Department of Energy Conversion and Storage \\ Technical University of Denmark, Denmark \\ Telephone: +4550199104
}

Email: glzhao9@gmail.com

\begin{abstract}
The objective of this paper is to provide a more detailed picture of potential biomass energy production in the Chinese energy system towards 2030 and 2050. Biomass for bioenergy feedstocks comes from five sources, which are agricultural crop residues, forest residues and industrial wood waste, energy crops and plants, animal manure, municipal solid waste. The potential biomass production is predicted based on the resource availability. In the process of identifying biomass resources production, assumptions are made regarding arable land, marginal land, crops yields, forest growth rate, and meat consumption and waste production. Four scenarios were designed to describe the potential biomass energy production to elaborate the role of biomass energy in the Chinese energy system in 2030. The assessment shows that under certain restrictions on land availability, the maximum potential biomass energy productions are estimated to be $18833 \mathrm{PJ}$ and $24901 \mathrm{PJ}$ in 2030 and 2050.
\end{abstract}

Keywords: Biomass Resource, Biomass Energy Production, China

\section{Introduction}

In recent years, it becomes more attractive to intensify the production and use of biomass to replace fossil fuels for the production of heat, electricity and transportation fuels. As biofuels can be less $\mathrm{CO}_{2}$ intensive than fossil fuels due to the fact that biomass, ultimately produced by the plants absorbing $\mathrm{CO}_{2}$ and transforming it through photosynthesis sugars and starches into sugars and starches in the growth phase. The difference between burning fossil fuels and biomass is the time perspective of carbon cycling among atmospheric $\mathrm{CO}_{2}$ and plant ecology. Making use of biomass resources as a substitute for fossil fuel is a rather recent strategy for many countries (Berndes, Hoogwijk and Van 2003; Lund and Mathiesen 2009; Mckendry 2002). This shift is now also going to take place in China and other developing countries. The fact is that biomass already provides roughly $35 \%$ of the energy demand in developing countries, mainly used as firewood for cooking and heating (Demirbas and Balat 2006; Hoogvijk et al 2006). In western countries, advanced technologies, such as efficient biomass conversion, are employed especially for using biomass for electricity. USA is leading the way in using biomass for electricity, which accounts for $26 \%$ of the world's total biomass used for electricity production, followed by Germany (15\%) Brazil and Japan (both 7\%). In China, biomass and waste energy production accounted for $8 \%$ of the national energy consumption in 2010. The major utilizations of biomass are the traditional and inefficient technologies. The power production based on biomass and waste was $2 \mathrm{TWh}$, which accounted for $0.06 \%$ of national power generation in 2008. By the end of 2010 biopower capacity reached 6.3GW. The power production based on biomass and waste was $11 \mathrm{TWh}$, which accounted for $0.2 \%$ 
of national power generation in 2010 (IEA 2012). Most of that electricity was generated from direct combustion of agricultural and forestry residues. This means that China has just started the transformation to an energy system based on more biomass.

The Chinese government realized that the development of the renewable energy industry plays a major role in responding to the energy crisis as well as the growth of associated environmental and greenhouse emissions. In the beginning of the $21^{\text {st }}$ century, the implementation of the Renewable Energy Law has established the legal foundation and development of renewable energy, which promotes the rapid development of biomass power generation in China (NPC 2006). China's national development and reform commissions and many other relevant governmental agencies have developed a series of policies and regulations to ensure that the electricity generated from the renewable resources can be purchased to the power grid (NDRC 2007). China introduced a mandate requiring grid companies to purchase all renewable electricity generated within their coverage areas. The Chinese regime has also established a series financial subsidy to sustain investment and production of biomass power generation. Firstly, the government offer financial subsidies for enterprises, according to the case of straw; secondly, offer subsidies for the grid feed-in engineering of biomass power generation projects; thirdly, there are also subsidies for the cost of operation and sustenance of an independent power generation system of renewable energy resource. However, the process for identifying potential strategies and decisions related to biomass power production are complex due to the diversity in specific biomass features and the differences in biomass-based technologies. Under the Chinese policy support, biomass power capacity rose very rapidly for several years, but growth has slowed in the past ten years due to limited availability of suitable biomass.

Biomass refers to organic materials produced from dead plants, trees and livings animals that feed on the plants. By the definition, we can say that biomasses are generally the byproducts of food production or human activities or the products from land occupation. The production of biomass energy will more or less relate to land use change and affect the food or wood production and ecosystem. It needs to address the questions of how much energy can be saved and how much that affects the environment (Wang et al 2010; Zhou et al 2011). Before promoting the biomass for energy use, the potential biomass production needs to be identified in China. Biomass energy is defined what is converted from natural plants and municipal solid waste in the supplementary of Renewable energy Law in China (NPC 2006). The source of biomass for energy feedstocks are identified five categories by Zhou, which are agricultural crop residues, forestry residues, biomass production of surplus degraded land, organic wastes and others(Zhou et al 2011), however, in Seubing's research, biomass comes from three sources: energy crops, agricultural and forestry residues and waste biomass (Seubing et al 2010). The complex covering of biomass source caused the different categories classification. In this paper, the biomass categories are identified as agricultural crop residues (AR), forest residues (FR) and industrial wood waste (IWW), municipal solid waste (MSW), animal manure (AM) and energy crops (EC) and woody crops (WC). Different biomass categories have their characteristics.

The objective of this paper is to explore the potential biomass energy production in China towards 2030 and 2050. The following steps are made to achieve this objective. In section one, the importance of biomass resource and energy are described. In section two, the method and 
approach to address the potential biomass resource and biomass energy are introduced. The assumptions related to biomass energy production are made, such as crop yields, conversation technologies, land use and so on. In section three, the potential productions of biomass and biomass energy are presented in four scenarios. In section four, the results of biomass energy production is discussed. And the potential role of biomass energy in the Chinese energy system in 2030 is analyzed. In the last section, the conclusion of biomass energy productions and unitization is presented.

\section{Method and Assumption}

\subsection{Potential land for biomass energy production}

Potential areas for biomass productions are needed to be identified as a preliminary to make a detailed assessment of the biomass source. Three biomass sources related to the land use are the agricultural crop residues, forest residues and industrial wood waste, and energy crops and woody crops. Animal manure and MSW are the byproducts of the human activities. Agricultural land is divided into five subcategories: 1) cultivated land, 2) forest land, 3) grassland, 4) garden land and 5) other land use related to agriculture. As the land source for biomass energy production, the amounts of agricultural land are dynamically instable, which was 631.377 million hectares in 2000 and increased to 631.434 million hectares in 2008 (NBS 2011). The primary driving power of land use change is due to the increasing food demand, ecological value, and political strategy (Heilig 1997; Lin and Ho 2005; Wang et al 2012). In the 90s, the demand for food sharply increased with the population explosion. The land for food production was over occupied, which caused environmental and ecological problems. The Chinese government encouraged to land storage and reforestation to keep land quality and protect the environment. The basic farmland protection policy and the law of land administration are two important laws guiding the land development in China. To safeguard food security, the State Council has set a minimum limit of 120 million hectares of cultivable land, quintupled tax on the utilization of arable land for other purposes, and excluded the use of grains and green grain crops for biofuel and other forms of bioenergy in 2007. The problem with them is that the entire quantity of cultivated land can be kept up, but the quality of the land is pressed down. The high-quality arable land in China is mainly in the same area as fast economic development and urbanization. The supplemental cultivatable land is from the poor quality land. China has lost much fertile land due to urbanization.

The lands, suitable for biomass production, are arable land, forest land and part of the unused land (marginal land etc.). The quantity of cultivated land has diminished from around 130 million hectares in 1998 to 121.7 million hectares in 2010. The average cultivated land for crops occupation was 127.8 million hectares from 1990 to 2010. It includes 104 million hectares of protected farmland and other arable land. Established in the biomass development strategy in China, the protected farmland is assumed not available for the biomass energy production. The potential arable land for energy crops is 23.764 million hectares. Forest area covered with trees was 181.38 million hectares in 2011 (SFA 2011). Based on the forest planning, the total amount of forest land will be 223.04 million hectares in 2020 (SFA 2010). The public service forest accounts for $56 \%$. The other forest land is commercial forest and land which can be freely cultivated for energy plants, which is estimated to be 97.2 million hectares. 
The marginal land is the poor condition land, but desirable for growing woody crops, which can be converted into energy. This includes shrub land, sparse forest land, dense grassland, moderate dense grassland, sparse grassland, bottomland, alkaline land, and barren ground. The line of marginal land for energy crops and plants will not affect the arable land and forest land occupation. Considering the low quality, marginal land can only be available for some of the woody crop cultivation (Zhuang et al 2011, Tang et al 2010). There were 61.1 million hectares of marginal land, which had been identified as suitable for biomass energy production (Li, Wang 2010, Guo, Hanaki 2010, Wang and Li 2011). Among the marginal land, 17.8 million hectares are suitable for bioethanol production; 43.3 million hectares are suitable for biodiesel production.

\subsection{Approach and Assumption}

There are two approaches to assess the potential biomass production, which is the demanddriven approach and the resource-focused approach. The resource-focused method is an approach, which is based on the total biomass resources and the rivalry between different uses of biomass resources (Hoogwijk, Faaij et al. 2003, Hoogwijk, Faaij et al. 2005). The demanddriven method estimates the total amount of biomass for energy use, which can meet the target of the energy supply (Asif and Muneer 2007). It is the rivalry between different biomass energy products of electricity and biofuels. The assessment of biomass energy is modeled on the national level. The national statistical date is the main date source, together with the scientific research. The principle of scenario development is to depict the potential biomass production and the biomass energy production in China in 2014, 2030 and 2050. Four scenarios are designated to carry out the assessment: $\mathbf{S}_{2014}, \mathbf{S}_{2030 \text {-low }}, \mathbf{S}_{2030 \text {-high }}$ and $\mathbf{S}_{2050}$. Each scenario describes the potential development of biomass production within a given time frame, depending on a number of factors like crop yields, land occupation and conversion technologies etc.. Table 1 outlines the scenario criteria and table 2 summarizes assumptions used in the scenarios.

The two most important factors, which decide the production of biomass energy, are the biomass productions and conversion technologies. Land utilization is an important factor related the potential yield of biomass sources. The current Chinese land use policy is against using existing arable land for the yield of biomass. Two land use assumptions are considered in the scenarios displayed below (Table 1). The first land assumption (L1) is that there will be no promotion of biomass for energy use. Energy crops and plants are cultivated exclusively on the marginal land. The second land assumption (L2) is that there will be an amount of tillable land which is available for energy crops and plant cultivation. The energy crops are accepted to be grown on the non-protection farmland along with the marginal land. Energy plants are free to be engrafted alongside the forest land except in public forest estate. Another factor which affects biomass productions is the crop yield. The biomass categories productions related to land used (AR, FR, IWW, EC, EP) are predicted based on the available land resources and production yields. The production of animal manure and MSW are predicted based on living standard assumptions and population.

Table 1 The scenario assumptions related the yields, land usage and conversion technologies 
Table 2 Explanations of the notation used in Table 1

\subsection{Agricultural crop residues}

Agricultural crop residues include straw and stalk, which are the byproducts of agricultural cropping practice (cultivation of farms and harvesting activities) and the byproducts of processing agricultural crop products like food or feed production process. The crops cultivated on arable land can be classified into five categories, which are grain crops, oil content crops, cotton, fiber crops and sugar crops. The grain crops include cereal crops (wheat, corn and rice), beans and tubers. Oil-containing crops include peanuts, rape, sesame and other oil crops. Sugar crops include sugarcane and sugar beet.

Generally, the characteristic of the land will not change very much; the difference is the distribution of land for different cultivation, which is driven by the demand for food or forest. Cultivated land allocation with different crops reflected diet change and food consumption. Some crops can supply not only food for humans but also feed for animals such as cereal crops and beans. The demand growth for crop products was projected to be lower toward 2050 compared to the past two years. The crops yields average annual growth towards 2050 has been estimated to be half of the historical growth rate from 1970 to 2007(Alexandratos and Jelle 2012). The demand for food also causes changes in land occupation between different crops, so it is assumed that the annual increased rate for land occupation for crops to 2050 is also half of the past years. Due to the data availability, the data of land occupation is from 1990 to 2014. In the period of 1990 to 2014, the annually increased rate for land occupation for grain crops was $0.04 \%$. Increased the annual rates of land occupied for oil crops, cotton fiber crops and sugar crops were $0.74 \%,-0.45 \%,-5.28 \%$ and $0.18 \%$ respectively. The land distribution in 2030 and 2050 is calculated based on half of the historical annual increase rate. In 2030, land occupation for grain crop accounts for $84.65 \%$ of the total cultivated land; oil crops occupy $11.00 \%$ of the cultivated land; the shares of cotton, fiber crops and sugar crops are $3.18 \%, 0.03 \%$, and $1.43 \%$ respectively (Table 3 ).

Table 3 Land distribution within crops categories in 2030 and 2050

Even though the yields of some crops went up and down each year, the crop yields were increasing gradually in the long term (NBS 2015). The annually increased yield rates of corn and rice are lower in China compared to the global average (NBS 2015, Jelle 2009). Although the increased yield rate of wheat is much higher than the global average, the wheat yields in developed countries like UK, Germany are still much higher than those in China (Jelle 2009). The yield increase is as a result of the intensification of the land use. It can use more fertilizer or increase the crop production technology. In the yield assumption (AR1), the overall yields of agricultural crops in 2030 and 2050 were estimated using the crop average productivity is modeled on half of theirs historical growth rate from 1990 to 2014, which is due to the slowing increase rateof food demand (Alexandratos and Jelle 2012). The productivity growth of crops is due to increased education and experience in planting crops as well as limited gains that can be gained through breeding and selection of better varieties. The amount of residues generated from these crop yields was calculated using available agricultural statistics. 


\subsection{Forest residues and Industrial wood waste}

Biomass resources from forest include both forest residues (primary residues) that is left over from cultivation and harvesting activities and industrial wood waste (secondary residues) which is those from any wood processing steps. The assessments of potential forest residues and industrial wood waste are based on the potential Chinese forest resources and forest growth rather than the forest felling and industrial wood consumption. The method employed to identify the potential forestry residues in China is the same method assessing potential energy from forest plantation in the EU (Asikaninen and Liiri 2008). The wood species are separated into three groups. The spruce group includes Picea sp., Larix sp., Abies sp. Another two groups are Pine group and broadleaved group, including Beech, Oak, Birch and other broadleaved trees. The percent of each group of tree in Chinese forests was calculated during the $7^{\text {th }}$ forest inventory. This inventory showed that $17.79 \%$ of the trees were from the pine group, $33 \%$ from the spruce group, and $49.21 \%$ from the broadleaved group. The share of each component of the trees is shown in Table 4, which is based on the previous research (Eggerst 2001; Marklund 1998).

Table 4 Proportions of biomass components used in the volume estimation

The national forest resource inventory was held every five years (Table 5). The first forest inventory started in 1973 and stopped in 1976. The standing stock was 8655.79 million $\mathrm{m}^{3}$. The standing stock increased to 14553.94 million $\mathrm{m}^{3}$ during the $7^{\text {th }}$ national inventory (SFA 2012). The protected forests are the most important component in forest resources.

Table 5 Standing stock from different national forest inventory (SFA 2012)

Timber forest is to produce timber. The Economic forest is to produce fruit, oil, seasoning, and medicine. Protected forest is aimed to protect resources, such as water, soil, etc. Firewood forest is planted as fuel. The special use forest can be used to experiment, act as a nature reserve, act as a landscape forest, and so on.

The protected and special use forests are mainly for public services, which are financed by the public department to protect or maintain the biological diversity or natural or cultural resources. The function of protection includes $60 \%$ for the protection of soil and water and $40 \%$ for multiple purposes. The harvested time depends on the protection capacity of the species. Generally, the lifetime of the coniferous forest is longer than that of the broad-leaved forest. The lifetime of a protection forest is between 20 to 50 years (Liu 2004; Jiang and Chen 2011). In our analysis, it is assumed that the protective ability of protected forests is 50 years. The primary use of timber and firewood forest is wood production. They would be reaped when the forest becomes mature. The lifetime of them is assumed to be 10 years (Zhang 2005). The special purpose forest is mainly for tree resource conservation, ecological and environmental protection, forest tour and scientific experiments, and so forth. The function of the special purpose forest includes $67 \%$ for the conservation of biodiversity and 33\% for social services (FAO 2010), which is not left to be cut or sold for any economic use. There will be no wood product or residue production from the special forest. The products of economic forests are 
mainly fruit, tea, and so forth. The biomass residues from the economic forest were identified as 400 million tons (Wang and Lv 2006).

In the forest planning, there will be 70 million hectares of afforestation in 2030. Trees will be planted on rural and city roads and so on, which will be 7 million hectares in 2030(SFA 2012, 2014). It is assumed that the 77 million hectares allocated for reforestation cannot be cut until 2060. The total forest land was planned at 223.04 million hectares and the public service forest accounts for $56 \%$ of this. The protected forest and special purpose forest will be 124.902 million hectares; the commercial forest occupied the rest of the timber land (L1). The protected forest is dedicated to the protection and maintenance of biological diversity, natural, and associated cultural resources. The other forest land is commercial land, which can be freely cultivated for woody crops (L2).

Based on the $7^{\text {th }}$ forest inventory, the annual forest productivity (FR) is $3.85 \mathrm{~m}^{3}$ per hectare (SFA 2014). The potential wood supply is estimated based on the potential stock, not the actual wood production. It is assumed that the standing volume timber forest will be harvested after the life time of 10 years. The collection of forestry residues starts from the forest management to the final timber harvest. The residue fraction of industrial wood residues and wood is 0.344 (Wang and lv 2006). The moisture content of the fresh wood material is from $50-55 \%$. The bulk density of fresh wood was $140-150 \mathrm{~kg} / \mathrm{m}^{3}$ (Bradley et al. 2009).

\subsection{Energy crops and Woody crops}

The energy crops are mainly divided into sugar content crops and oil content crops. Sugar crops are planted mainly for in the sugar industry, and oil crops are mainly for food oil products. There are more than 4,000 species of plants in China with the potential for bioenergy production, which are identified in several studies (Zhuang et al 2011; Tian et al 2006; Yu and Tao 2009). The potential sugar crops suiting for bioethanol production were sugarcane, sweet sorghum, cassava, sweet potato, potato, and corn, which were distinguished by the ministry of agriculture in China in 2007 (MOA 2007). A shift to 'non-food based' biofuel was proclaimed and supported in accordance with the Renewable Energy Law, which outlines economic incentives and supervisory measures by the government. Based on the planning, there should not be a competition between energy crop production and food production. So corn and potato are excluded from the sugar crops, as they are also food crops. Another crop selected as a sugar crop is Jerusalem artichoke, which can be cultivated on marginal land. Sugarcane is grown between the Tropic of Cancer in northern China. Sugar beet is a one of the major sugar and economic crop in northwest, northeast and northern of China (Wang and Li 2011). Cassava, which is grown in the south of China, can be tolerant to drought and there for is productive in poor countries. Sweet sorghum, which has a high tolerance to drought and water logging, can be planted on saline and alkali soils in China.

Oil crops are mainly soybean and rapeseed in China. Both soybean and rapeseed are cultivated for food and feed production. Woody crops are trees with oilseed and trees with starch fruit, which are planned by the forest administration of China. Four oil plants were identified for biodiesel production, which are Jatropha curcas, xanthoceras sorbifolia, Pistacia chinesis Bunger, and Swida wilsoniana Sojak (Guo and Hanaki 2010). In this study, soybean is also taken as the potential oil crops to modify the arable land for energy crop cultivation, even though it is also a food product in China. Jatropha curcas is a small shrub tree belonging to the Euphorbiaceae family. It is widely cultivated in tropical and subtropical 
regions and is mainly found in the hot, dry valleys of the southwest of China. Xanthoceras sorbifolia is one of the important plant species, in terms of edible oil and bio-diesel production, but little information on the seed characteristics have been described thus far. It can grow in temperate regions and is found in north China, east China and northwest of China, including 14 provinces (municipalities and autonomous regions).

The low yields are calculated based on the current yield's increased rate. Higher yields are based on the estimated yields of other studies. The annual increased yield rates of cassava, sweet potato, sweet sorghum, sugarcane, sugar beet and soybean are $0.92 \%, 1.59 \%, 0.48 \%$, $0.69 \%, 4.23 \%$, and $1.13 \%$ respectively. The high yields of cassava, sweet potato and sweet sorghum are also based on previous research ( $\mathrm{Li}$ and Wang 2010). The yield of sugar beet is lower in China than the other countries, even though the annual increased rate was high. So the high yield of sugar beet is based on the potential yield of sugar beet (Wang and Li 2011, Balat and Balt 2009).

\subsection{Animal manure and MSW}

Animal manure is also an important biomass source for energy production, especially biogas which can be further used for cooking and heating in small scale, or for power and heat generation in big scale. The potential manure production depends on animal production and the lifetime of animals (Zhang and Gao 2004). The animal production includes cattle and buffaloes, horse, donkey, mule, pig, sheep, and poultry. Poultry was the type of animal with the highest total production, followed by pig, sheep and cow. Poultry includes chicken, duck and goose. The lifetime of poultry has been calculated to be 55 days, when using chicken as the poultry standard. The amount of slaughtered poultry is taken to calculate the manure production. The total amounts of pigs in the calculation uses the number of the slaughtered pigs, as the pig's feeding lifetime is 199 days. The normal lifetime of the cow is more than 1 year. The total amount of cows by the end of the year is taken to calculate manure production. The lifetime of sheep, horse, donkey and mule are also more than 1 year; the total amounts of feeding animal by the end of the year are taken to calculate the manure production. The animal feces parameters of cow, horse, donkey, mule and sheep are 10.1, 5.9, 5.0, 5.0 and $0.87 \mathrm{ton} / \mathrm{yr}$. The animal feces parameters of pig and poultry are 5.3 and $0.1 \mathrm{~kg} /$ day (Wang and Ma2006).

Animal manure is the byproduct of meat consumption, thus, the production of animal manure is determined by the meat demand. The average meat consumption per capita in China is still only half of the world average, but the demand for meat has been increasing and is expecting continue to increase in the future (Ranganathan, J etc. 2016). The meat consumptions in 2030 and 2050 are predicted in two assumptions of meat annual increase rates. The first assumption is based on the increase rate of the world average annual meat consumption per capital towards 2050, which is $0.66 \%$ (AM1) (Alexandratos and Jelle 2012). The second assumption is based on the Chinese historic annual meat production increase rate from 1990 to 2014, which is $3.38 \%$ (AM2) (NBS 2015). Another important determining factor of energy production from animal manure production is the dry matter. The dry matter is between $12.8 \%$ and $22 \%$, depending on the kind of animal manure (Peters et al 2003). The core components are the same to the current meat production in 2014 in both assumptions. Animal manure production was still mainly from sheep, cattle and buffalo, pig, which account for around 95\% of total manure production (Fig. 1). For the pig, cattle, and sheep manure, the water content is 
$82 \%, 83 \%$ and $70 \%$ respectively. It is assumed that the water content of the other animal manure is $80 \%$.

Figure 1 The potential production of animal manure in four scenarios unit: $10^{12} \mathrm{~kg}$

Municipal solid waste (MSW) is composed of daily refuses from citizens' commercial service and a small amount of waste from construction activities. Its composition and amount depends on various factors such as population, resident income, food preferences, urban construction, seasonal influence, etc. The annual MSW disposal was 114 million tons in 1990 and increased to 179 million tons in 2014. The national average annual MSW generation was $238 \mathrm{~kg}$ per person from 1990 to 2014 (NBS 2015). Even the national MSW disposal increased each year; the MSW generation per person did not increase as large as the total production. The reason for that would be urbanization. China still has a long way to go in its industrialization, urbanization and modernization. The increased number of citizens increased the total MSW generation. There was still large population having a low living standard, especially for the people who moved from rural areas to cities (Jiang, Sommer and Christensen 2011). The MSW production is estimated based on the national average volume of MSW generated in 2014. The population in urban cities in China predicted by United Nation will be 998.92497 million in 2020 and 1037.6955 million in 2050 (UN 2011). The national MSW generation will be 246.04 million tons in 2030 and 259 million tons in 2050 .

\section{Results}

\subsection{Potential energy production from agricultural crop residues}

Agricultural crop residues are calculated based on the production of agricultural products and residue to product ratio of each crop. The potential crop yields are predicted based on the annual increased rate. The productions of crops residues are estimated based on the crop yields and the residue to product ratio, which is affected by internal and external factors, e.g. crop breeds, soil condition and local environment. The theoretical production of agricultural crop residues is estimated to be 131 million tons in 2014 (Table 6). The crop residues yield increased with the increasing crop yields until a certain level of crop yield (Bentsen et al. 2014; Fischer et al. 2014). It is assumed that the residue yield will not increase with the level of crop yield until 2014. Based on this assumption, the residues to product ratios of main crops are estimated at 2030, and 2050 (table 6). The potential agricultural crop residues are identified with crop yields and land use scenarios. The average crop residues productions are predicted to be $1.0 \mathrm{t} / \mathrm{ha}$ and $1.06 \mathrm{t} / \mathrm{ha}$ in 2030 and 2050 respectively. The difference between the average crop residue yields is due to the land occupation among the crops. The largest crop residues productions are from corn, rice, sugarcane and wheat crops. Corn, rice and wheat are the principal food grain crops for food output.

Table 6 Agricultural crop residues production in the scenarios 
Sources: The production of agricultural crops is from Chinese statistics yearbook 2014 (NBS 2015), the residue to product ratio is based on (MOA 1998; Cui and Zhao 2008), the water content reference (Niu and Liu 1984).

Interpretation and definition

* The water content is based on (Niu and Liu 1984). The water content in the crops that lack data is assumed to be $85 \%$. The normal dry content of agricultural residues is $15-20 \%$. We take the low limit.

The national collection efficiency of crop residues is assumed to be $85.9 \%$, which is the largest collectable efficiency in the literature (Cui and Zhao 2008, MOA 2010). The low heat value (LHV) of crop residue is $14.5-18.2 \mathrm{MJ} / \mathrm{kg}$, depending on the hydrogen content of the crops (MOA 2010). The energy productions from crop residues are estimated to be 390$821 \mathrm{PJ} / \mathrm{yr}$ in the four scenarios (Fig. 2). The different results reveal the different assumptions of land use, crops production and conversion efficiency. The most productive scenario is the biomass energy production in $2050\left(S_{2050}\right)$ due to the increasing of conversion efficiency. Even though the land occupations of crops are the same in $\mathbf{S}_{2014}$ and $\mathbf{S}_{2030 \text {-low }}$, the reason the biomass energy production in $\mathrm{S}_{2030 \text {-low }}$ is a little higher than in $\mathrm{S}_{2014}$ is that the land occupation of crops have changed because of food demands. Due to the increasing conversion efficiency, the biomass energy production is much higher in scenario $S_{2030 \text {-high }}$ than that in scenario $S_{2030 \text { - }}$ low, even though the total land occupation is deceased. Although the land occupation is limited by the agricultural crops, biomass energy production from crops residues in $S_{2050}$ is still much higher than productions in other scenarios because of the higher conversion efficiency. The estimations vary due to the variability in yield, conversion efficiency, and potential land for energy crops in the time to come.

Figure 2 Energy production from agricultural crop residues in the four scenarios Unit: PJ

\subsection{Potential energy production from forest residues and industrial wood waste}

In our assessment of forest biomass production, it only looked at the potential FR and IWW production. Potential wood production is not included in the estimation, as the wood production is assumed to be utilized as timber. The potential forest residue production are estimated to be 163.80-230.92 million $\mathrm{m}^{3}$; the potential industrial wood waste production is estimated to be 81.09-125.42 million $\mathrm{m}^{3}$ (Table 7). The different results are due to assumptions of forest land occupation. The productions of both FR and IWW in L2 are lower than that in L1, as the forest land plantation is reduced because of woody crop land occupation. The reason FR and IWW have the same productions in $\mathbf{S}_{2030 \text {-high }}$ and $\mathbf{S}_{2050}$ is that forest biomass is estimated based on the same forest productivity and land assumption.

Table 7 Potential forest residue production in the four scenarios Unit: million $\mathrm{m}^{3}$ dry matter

The potential forest biomass energy productions are estimated 169-314 PJ/yr in the scenarios (Fig. 3). The energy production in $S_{2050}$ is much higher than that in $S_{2014}$ and $S_{2030}$. The reason for that is the employing of high-efficiency conversion technology in $\mathrm{S}_{2050}$. 
Figure 3 Energy production from forest residues and industrial wood waste in the four scenarios Unit: PJ

\subsection{Potential energy production from energy and woody crops}

The energy and woody crops do not cover all the energy crops and energy trees in China. There are two main reasons for choosing 10 types of energy and woody crops. The first reason is that the physical soil conditions are suited for these crops and plants in China. The second reason is that these energy and woody crops have a wider national covering. Some of them are suited for the northern China; the others are suited in the southern China. The potential productions of energy crops and energy plants are estimated based on assumptions of yields and land occupations in the scenarios (Table 8).

Table 8 Potential production of energy and woody crops in the three scenarios unit: million tons

In $\mathrm{S}_{2030-\text { low }}$, the energy and woody crops are cultivated on marginal land, which is 61.1 million hectares. Among them, 17.8 million hectares is available for energy crops cultivation; 43.3 million hectares is available for woody crops cultivation. With the same yield assumption, the energy crops are cultivated on non-protected farmland and woody crops are planted on commercial forest land as well as marginal land in $S_{2030 \text {-high }}$ and $S_{2050}$. The highest bioenergy production is estimated based on the high yield assumption and land expansion in $\mathrm{S}_{2050}$. In our assessment, the potential energy productions from energy crops are estimated 2812$10624 \mathrm{PJ} / \mathrm{yr}$; the potential energy productions from woody crops are estimated 4972$11805 \mathrm{PJ} / \mathrm{yr}$, due to the yields and land assumptions (Fig. 4). In scenario $\mathrm{S}_{2014}$, it is assumed that bioenergy was not planned to be in mass production. The total bioenergy production is estimated to be $22429 \mathrm{PJ} / \mathrm{yr}$ in 2050 from 61.1 million hectares of marginal land, 24 million hectares non-protect arable land occupation and 97.2 million hectares non-protected forest land.

Figure 4 Potential energy production from energy and woody crops in the four scenarios Unit: PJ

\subsection{Potential energy production from animal manure and MSW}

The potential energy productions from animal manure are estimated to be 221-695 PJ/yr in the four scenarios (Fig. 5). The different results are due to the different assumptions of meat consumption. In the Chinese countryside, biogas is an important energy supply for cooking, which has been used by 40 million families by the end of 2010 (Zhang 2010).

Due to urbanization, the annual MSW generation per person has not changed significantly in the last 10 years. Even though people in the cities improve their lives a lot, more and more people who moved from the countryside have a low standard of living. The potential energy productions from MSW are estimated to be 121-505 PJ/yr in the four scenarios, assuming 30\% 
of the total potential MSW is used (Fig 5). The different results are due to the waste generation per capital and employed conversion technology.

Figure 5 Potential energy production from animal manure and MSW in the four scenarios Unit: PJ

\subsection{Potential biomass energy production}

The biomass energy production is estimated considering the potential biomass resource and conversion technology. Based on these assumptions, the overall biomass energy productions are predicted in the four scenarios (Fig. 6). Our assessment indicated that the overall biomass energy production could come up $24901 \mathrm{PJ}$ in the scenario with limited biomass energy promotion in 2050. The energy production from energy crops and energy plants increase from 7785 in $\mathrm{S}_{2030 \text {-low }}$ to $22400 \mathrm{PJ}$ in $\mathrm{S}_{2050}$, which accounts for more than $82 \%$ of total biomass energy production in 2050.The energy production from crop residues can come up to $821 \mathrm{PJ}$ in 2050, which is the second largest biomass energy production in the future besides energy and woody crops. In our estimation, the energy production from MSW is 505 PJ in 2050, which generated from $30 \%$ of the total MSW production. Energy and woody crops dominate the total potential biomass energy supply in these three scenarios. The largest biomass energy production lies in large-scale energy plantations in areas with a favorable production of biomass, which means that estimates of plantation areas, surplus agricultural land and energy crop yield are central to the assessment.

Figure 6 Potential biomass energy supply in China in the four scenarios Unit: PJ

\section{Discussion}

\subsection{Potential role of biomass energy in the Chinese energy system}

China's energy system has been highly dependent on fossil fuels since the beginning of the $20^{\text {th }}$ century. The national renewable energy targets were set in the Renewable Energy Law in 2006 and supplemented in the mid-and long-term regulation in 2007. China aimed to raise its share of renewable energy in primary energy consumption up to $10 \%$ by 2010 and $15 \%$ by 2020. In 2010, as a share of primary energy consumption, coal still accounted for $68 \%$ and renewables only accounted for $7.9 \%$. In that sense, China did not achieve its targets, although they were moving in the right direction. In 2016, the Chinese government signed the Paris Agreement on climate agreement to cut its carbon emissions per unit of GDP by $60-65 \%$ by 2030 from the 2005 levels. China also aimed to increase the share of non-fossil fuel sources in primary energy consumption to about $20 \%$ and peak its carbon emissions by 2030 (Wang 2016).

The potential biomass energy production could reach $8905 \mathrm{PJ} / \mathrm{yr}$ without land expansion $\left(\mathrm{S}_{2030 \text {-low }}\right)$. The biomass energy productions converted from crops and forest residues are not as large as the other biomass sources. The reason is that AR and FR are the byproducts of food and timber demand, and China has a lower capacity of production compared to the consumption. The same reason can apply for relatively low energy production from animal manure. The biomass energy production from MSW will continue to increase due to urbanization and population increase. With current biomass conversion technology, the 
biomass energy production could provide up to 18833 PJ in 2030 with only limited land expansion $\left(\mathrm{S}_{2030 \text {-high }}\right)$. According to IEA, the energy consumption, which is predicted to be $157046 \mathrm{PJ}$ in 2030, will continue to increase because of the rapidly developing economy and population (IEA 2015). In the bridge scenario by IEA, the share of biomass and waste energy account for $7 \%$ of total energy consumption in 2030, which is higher than the energy scenarios in the world energy outlook. Based on our biomass assessment results, biomass energy can account for 5\% to $15 \%$ of the total primary energy consumption in 2030 (Fig.7). In this calculation, the biomass sources are predicted in different scenarios with different assumptions, such as land occupation and the efficiency of conversion technologies. The potential biomass energy can provide up to $15 \%$ of the energy demand in 2030 just after coal, oil and gas, and become the greatest renewable energy resource. Thus far, China's government does not possess a specific target of biomass energy in the future energy system. Biomass has the potential to be an important source of renewable energy to satisfy the increasing energy need in China. However, the largest biomass energy production depends on land expansion for energy crops by taking area now used for food cultivation.

Figure 7 Potential biomass energy in the Chinese energy system in 2030

\subsection{Comparison with previous studies}

A better assessment of the potential biomass resource supply is required to consider the significant use of biomass in the future energy system. A number of resource-focused subject areas with a different geographical scope have been constructed in later years to study the possible provision of biomass energy in China.

It should be mentioned that these studies differ from each other, as well as from this study, in several aspects, such as scope, land assumption, the regions defined and time frame. There is no research paper that attempts to assess the potential national biomass energy production in China in 2050 so far. Our study modeled projections and assessments based on assumptions regarding energy crop plantation areas, yields etc. The resource-focused approach is used in this paper, as well as by Wang and Zhou (Wang et al 2010; Zhou et al 2011). In these studies, the assessments of biomass production are based on similar approaches, but the result is different. In our research, the AR production is 131 million tons in 2014 to 116 million tons in 2050, which is higher than the research from Wang and Zhao, which predicted 750 million tons in 2007 and 690 million tons in 2008 respectively. In this study, the relative wide scope of crops is taken into calculation, e.g. sugarcane, bagasse and cotton. Another reason is that the biomass residue productions are estimated based on the crop productions in 2014 . Compare to these two former studies, the production of crop residues is estimated based on dry matter and the collectible efficiency, which is also considered in our assessment.

Energy and woody crops will dominate the total potential biomass supply in the future scenarios, which signifies that the estimates of plantation areas, marginal land and energy crop yields are central to the assessment. Zhuang had identified the marginal land, which is suitable for energy crops and plants cultivation, to be 43.73 million hectares (Zhuang et al 2011). In scenario $S_{2030-\text { low }}$ of our study, marginal land suitable for bioethanol production is estimated 17.8 million hectares; 43.3 million hectares are suitable for biodiesel production, which is a close to the previous study. Most of the previous studies have identified the 
marginal area for one specific energy crops: Zhang had predicted the potential marginal land for sweet sorghum is to be 0.7 million hectares and Tian had predicted the potential marginal land for cassava to be is 0.38 million hectares (Zhang and Xie 2010; Tian and Lu 2010). There were 5 million hectares suitable for sweet potato and 1.5 million hectares for molasses production based on Li's study ( $\mathrm{Li}$ and Wang 2010). The problem with the individual energy crop land distribution is that the distributed land might overlap. Overall, the potential land suitable for energy and woody crops cultivation is determined by previous studies. The uncertainty of the assumptions of the crucial parameter's land availability and output levels in energy crop production are the major reason for the divergence between the various. Thus, the outcomes of the studies are subject to widely varying opinions and assumptions for underlying scenarios.

\subsection{Uncertainty related to land use}

This paper presents a detailed assessment of potential biomass energy production in China in 2030 and 2050. Our analysis shows that the potential biomass energy production from land occupation, especially energy and woody crops, is greater than other sources in all scenarios. The major reason for the differences between the results in the scenarios is that land availability in energy crop productions are subject to widely varying opinions and assumptions for underlying scenarios. Even though China had strived to be self-sufficient in food production, the consumptions of agricultural products have been higher than the domestic production since 2003. For cereal, China started as an export country and turned into an importing country around the year 2004. It probably would still need more cereal imports in the near future. There are a large proportion of soybeans from imports, as the consumption of soybeans were twice as large as the domestic production in 2015 (NBS 2015). Currently, soybeans have not allowed to be used for biofuel production in China. Soybeans is used as food for both humans and animals. It is obvious that China needs more food with the population increasing and diet changing in the future.

In the light of current biomass energy policy in China, energy crops should not be regarded as a competitive alternative to food crops. The energy crops can only be cultivated on a limited amount of land (NDRC 2007). The biomass energy production should be enhanced by increasing crop yields and efficiency of conversion technologies. In scenario $\mathrm{S}_{2030 \text {-low, the }}$ planted areas for energy and woody crops are based on the marginal land. Food production and forestation cultivation are put in the priority of land use over energy crops by assuming that agricultural land is used in the first place to ensure national food self-sufficiency. Although taking out areas for energy feedstock cultivation based on the precept of no competition with food production, the reality proves that competitions between food and nonfood crops do exist.

In fact, it is extremely difficult to estimate the future land available for energy and woody cropscultivation. Energy and woody crop cultivation would face competition from several other kinds of land users, including food production, timber production, feed production, and so on. The increased food demand is met either from arable land expansion or land intensification in China or importing from the global market, but the amount of arable land is limited in China. There has been growing awareness of the importance of the functions of forests besides the wood production, such as protection of water and soil, biodiversity etc.. In accordance with this, the conservation of biodiversity and ecology are now receiving the same 
attention from the sustainable wood supply policy objectives. In general, energy crops enjoy the same land type as agricultural crops and woody crops enjoy the same land type as forest trees. In scenario $S_{2030 \text {-high }}$ and $S_{2050}$, energy crops are assumed to cultivate on the nonprotected farmland and woody crops are assumed to be planted on the non-protected forest land. The interests of farmers would be an important factor which affects the actual land cultivation for energy crops and plants. At a global scale, displacing food crops with energy crops in China may result in land use changes through the global food market. The pressure of food and timber demand will move to the global agriculture and forestry market. The consequence of a higher biomass energy demand is higher prices and deeper incentives for farmers to increase their output, possibly through the conversion of agricultural land (FAO 2009, Conforti 2011). The consequence of food production decreasing would lead to higher prices for food too.

\section{Conclusion}

This study indicates that domestic biomass could contribute significantly to the total energy supply in China towards 2030 and 2050. The production varies largely depending on a number of assumptions. For the scenario $\left(\mathrm{S}_{2030 \text {-low }}\right)$, which considers only the marginal land for the bioenergy feedstock cultivation, the total amount of biomass energy will be $8905 \mathrm{PJ} / \mathrm{yr}$ in 2030. Agricultural residues from food and feed production can account for $398 \mathrm{PJ} / \mathrm{yr}$; supplies from forestry, both residues and industry wood waste, can produce amount $280 \mathrm{PJ} / \mathrm{yr}$. The biomass energy from energy and woody crops can produce amount $7885 \mathrm{PJ} / \mathrm{yr}$. For the scenarios $\left(S_{2030 \text {-high }}, S_{2050}\right)$, which considers the limited arable land and forest land for bioenergy feedstock plantation, the biomass energy from energy crops and energy plants can produce $16731 \mathrm{PJ} / \mathrm{yr}, 22429 \mathrm{PJ} / \mathrm{yr}$ in 2030 and 2050 respectively. The maximum sum of total biomass energy production for all resources can amount $18833 \mathrm{PJ} / \mathrm{yr}$ by 2030 and $24901 \mathrm{PJ} / \mathrm{yr}$ by 2050 .

The prediction of the amount of biomass and its sources under certain restrictions on land availability shows that the biomass energy has the potential ability to be the third largest energy source in China's energy system, just after fossil fuels. However, the consequence of the promoting the land-related biomass categories might cause inappropriate land cultivation activity, especially since our assessment show that the largest biomass potentials lie in energy crops. In summary, as one of the most promising energies in the future, biomass energy has broad prospects for development in China. Although there may be some challenges and bottlenecks on the future path of development, it is not insuperable.

\section{Reference}

Alexandratos N. and Jelle B. 2012. World agriculture towards 2030/2050: the 2012 revision. ESA Working paper No. 12-03. Rome, FAO

Asif, Muhammad and Tariq Muneer. 2007. "Energy Supply, its Demand and Security Issues for Developed and Emerging Economies." Renewable and Sustainable Energy Reviews 11(7): 1388-1413.

Asikainen A.and Liiri H. 2008. Forest Energy Potential in Europe (EU27). Retrieved 06/03/2014 from http://www.metla.fi/julkaisut/workingpapers/2008/mwp069.htm: 
Balat M, Balt H. 2009. "Recent trends in global production and utilization of bio-ethanol fuel.’' Applied Energy 86(11):2273-2282.

Bentsen, NS, Felby C, Thorsen BJ: 2014. “Agricultural residue production and potentials for energy and materials services. ' Progress in Energy and Combustion Science 40(0): 59-73.

Berndes, G, Hoogwijk M, Van R. 2003. ', The contribution of biomass in the future global energy supply: a review of 17 studies.' Biomass and Bioenergy 25(1):1-28.

Bradley D, Diesenreiter F, Wild M, Tromborg E. 2009. World biofuel maritime shipping study. Task 40. Retrieved 06/09 /2014 from

http://www.bioenergytrade.org/downloads/worldbiofuelmaritimeshippingstudyjuly120092df. pdf.

Conforti P, 2011. Looking ahead in world food and agriculture: perspectives to 2050. Food and Agriculture Organization of the United Nations (FAO).

Cui M, Zhao L. 2008. “Analysis and evaluation on energy utilization of main crops straw resources in China.' 'Transactions of the Chinese Society of Agricultural Engineering 24(12): 291-296.

Demirbas M.F, Balat M. 2006. "Recent advances on the production and utilization trends of bio-fuels: A global perspective.' Energy Conversion and Management 47(15-16):2371-2381.

Eggerst T. 2001.The impact of manufacturing and utilization of wood products on the European carbon budget. Göttingen Germany: Institute of Forest Resource Management.

FAO(Food and Agriculture Organization), 2010. Global forest resources assessment 2010China. Retrieved 06/10/2014 from http://www.fao.org/forestry/fra/67090/en/chn/.

FAO (Food and Agriculture) 2009. How to Feed the World in 2050, Rome: High-Level Expert Forum 2009. Retrieved 06/01/2016 from

http://www.fao.org/fileadmin/templates/wsfs/docs/expert_paper/How_to_Feed_the_World_in 2050.pdf

Fischer R., Byerlee D. and Edmeades G. 2014. Crop yields and global food security: will yield increase continue to feed the world? ACIAR Monograph No. 158 edn. Canberra.

Australia: Australian Centre for International Agricultural Research.

Guo R, Hanaki K. 2010. "Potential and life cycle assessment of biodiesel production in China. ' Journal of Renewable and Sustainable Energy 2(3):01-15.

Heilig G K. 1997. “Anthropogenic Factors in Land-Use Change in China.’ Population and Development Review 23(1): 139-168.

Hoogwjk M, Faaij A, Van den Broek R, Bernders G, Gielen D. and Turkenburg W. 2003. "Exploration of the ranges of the global potential of biomass for energy. " Biomass and Bioenergy, 25(2): 119-133.

Hoogwijk M, Faaij A, Eickhout B, De vries B, Turkenburg W. 2005. "Potential of biomass energy out to 2100, for four IPCC SRES land-use scenarios.' Biomass and Bioenergy 29(4):225-257.

IEA (International Energy Agency), 2015. World Energy Outlook Special Report 2015: Energy and Climate Change. Retrieved 06/06/2016 from 
https://www.iea.org/publications/freepublications/publication/WEO2015SpecialReportonEner gyandClimateChange.pdf.

Jelle B. 2009. The resource outlook to 2050 by how much do land, waste and crops yields need to increase by 2050? Food and Agriculture Organization of the United Nations.

Retrieved 06/05/2014 from

http://www.fao.org/fileadmin/templates/wsfs/docs/expert_paper/How_to_Feed_the_World_in 2050.pdf:

Jiang J, Chen A. 2011. 'Study on regeneration cutting age of shelter belt in Aohan county.', Inner Mongolia Forestry Investigation and Design 54(5): 16-17. Chinese.

Jiang X, Sommer S G, Christensen K V. 2011. “A review of the biogas industry in China." Energy Policy 39(10):6073-6081.

Li H, Wang L. 2010. "Potential of $\mathrm{CO}_{2}$ emission reduction by developing non-grain based bioethanol in China.' Environmental Management 46(4):555-564.

Lin G. C. S, and Ho S. P S. 2005. "The State, Land System, and Land Development Processes in Contemporary China.' Annals of the Association of American Geographers 95(2): 411-436.

Liu G. 2004. "The analysis of the farmland protection forest replanted in the Northeast of Liaoning Provence.' Protection Forest Science and Technology 2 (29): 36-37. Chinese

Lund H, Mathiesen B.V. 2009. 'Energy system analysis of $100 \%$ renewable energy systems-The case of Denmark in years 2030 and 2050.' Energy 34(5):524-531.

Marklund L G. 1998. Biomass functions for pine, spruce and birch in Sweden. Department of Forest Survey: Swedish University of Agricultural Sciences.

Mckendry P. 2002. 'Energy production from biomass (part 1): overview of biomass.' Bioresource technology; 83(1):37-46.

MOA (Ministry of Agriculture). 1998. Assessment of biomass resource availability in China. Beijing. Chinese.

MOA(Ministry of Agriculture). 2007. Agricultural biomass energy development plan(20072015). Chinese.

MOA(Ministry of Agriculture). 2010. National inventory and evaluation report of crop straw resources Ministry of Agriculture of China. Chinese.

NBS (National Bureau of Statistics) ed. 2015. Chinese statistic yearbook 2015. Beijing:

Chinese.

NDRC (National Development and Reform Commission). 2007. Medium and Long-Term Development Plan for Renewable Energy in China. Chinese.

Niu R, Liu T. 1984. Agricultural technology economy Manual. Agriculture Press. Chinese.

NPC(National People's Congress). 2006. The Renewable Energy Law of People's Republic of China. Chinese.

Peters J B, Combs S, Hoskins B, Jarman J, Kovar J. 2003. Recommended methods of manure analysis. (A3769). http://learningstore.uwex.edu/assets/pdfs/A3769.PDF 
Ranganathan J, Vennard D, Waite R, Dumas P, Liipinski B. and Searchinger T. 2016. Working paper, installment 11 of "creating a sustainable food future", shifting diets for a sustainable food future. Washington, DC, USA: World Resources Institute.

Seubing B, Zah R, Waeger P, Ludwig C. 2010. "Bioenergy in Switzerland: Assessing the domestic sustainable biomass potential.' Renewable and Sustainable Energy Reviews 14(8): 2256-2265.

SFA(State Forestry Administration). 2010. National forest land Protection and Utilization Plan 2010-2020. Chinese. http://www.forestry.gov.cn/uploadfile/main/2010-8/file/2010-8-25782d45dbdeea41398ff31b1023814c13.pdf:

SFA(State Forestry Administration). 2011. China's forestry general situation in 2011. Chinese. Retrieved 06/10/2012 from http://www.forestry.gov.cn/uploadfile/main/2011-12/file/2011-1221-d835a996f1c6464597e3a86914fecabb.pdf

SFA(State Forestry Administration). 2012. Main data of the $7^{\text {th }}$ National forestry inventory. Retrieved 06/10/2012 from: http://www.forestry.gov.cn/portal/main/s/65/content-90.html. Chinese.

SFA(State Forestry Administration). 2014. National Afforestation Plan(2011-2020).

Retrieved 01/05/2014 from http://www.forestry.gov.cn/uploadfile/main/2011-7/file/2011-712-8920476e3e204817a8d33e821e5fdb44.pdf. Chinese.

Tang Y, Xie J, Geng S. 2010. “'Marginal Land-based Biomass Energy Production in China.' Journal of Integrative Plant Biology 52(1):112-121.

Tian Y, Lu S. 2010. "The potential biomass energy development based on cassava in China." Journal of Anhui Agri. Sci. 38(28):5763-5766.

Tian Y, Zhao L, Meng H, Sun L, Yan J. 2009. "Estimation of un-used land potential for biofuels development in (the) People's Republic of China.' Applied Energy 86, Supplement 1(0): 77-S85.

UN(United Nations).2011. World Urbanization Prospects, the 2011 Revision. Retrieved 06/08/2012 from: http://esa.un.org/unpd/wup/index.htm.

Wang X, Lan T, Huan W. 2010. “'Assessment of Biomass Energy Production Potential in China.'” Power and Energy Engineering Conference (APPEEC) Asia-Pacific 1-4.

Wang F, Ma W. 2006. "The estimation of the production amount of animal manure and its environmental effect in China.'” China Environmental Science 26(5):614-619. Chinese.

Wang G, Lv W. 2006. The inventory of potential nurturing and development of forest biomass resources in China. China Forestry Industry 1:12-21.Chinese.

Wang J, Chen Y, Shao X, Zhang Y, Cao Y. 2012. "'Land-use changes and policy dimension driving forces in China: Present, trend and future.' Land Use Policy 29(4): 737-749.

Wang Y, Li C. 2011. 'Research Progress on Sugar beet Cultivation Model in China.'” Sugar Crops of China 01(55):55-58. Chinese.

Wang Y. 2016. China signs paris agreement on climate change.

http://news.xinhuanet.com/english/2016-04/23/c_135305180.htm. Updated 2016. Accessed 06/06, 2016. 
Yu S, Tao J. 2009. “'Simulation-based life cycle assessment of energy efficiency of biomassbased ethanol fuel from different feedstock in China.'” Energy 34(4):476-484.

Zhang C, Xie G.2010. "The productive potentials of sweet sorghum ethanol in China." Applied Energy 87:2360-2368.

Zhang K, Gao H. ed. 2004 The disposal and pollution treatment of livestock. Beijing: Chemical Industry Press. Chinese.

Zhang S. 2005. "Study on the Comprehensive Decision of Yielding Age of Short Rotation Timber Plantation.’’ Beijing Forest University. Chinese.

Zhang T. 2010. The $8^{\text {th }}$ National Congress of the China Biogas Society. China Biogas Society. Chinese.

Zhou X, Wang F, Hu H, Yang L, Guo, P, Xiao B. 2011. “'Assessment of sustainable biomass resource for energy use in China." Biomass and Bioenergy 35(1):1-11.

Zhuang D, Jiang D, Liu L, Huang Y. 2011 “'Assessment of bioenergy potential on marginal land in China.'’ Renewable and Sustainable Energy Reviews 15(2):1050-1056. 